\title{
Possible effects of ocean acidification on coral reef biogeochemistry: topics for research
}

\author{
Marlin J. Atkinson ${ }^{1, *}$, Pascale Cuet ${ }^{2}$ \\ ${ }^{1}$ University of Hawaii, Hawaii Institute of Marine Biology, PO Box 1346, Kaneohe, Hawaii 96744, USA \\ ${ }^{2}$ Université de la Réunion, Laboratoire d'Ecologie Marine (ECOMAR), 15 Avenue René Cassin, BP 7151, \\ 97715 Saint-Denis, Messag Cedex 9, France
}

\begin{abstract}
This paper is a short review of recent literature on how ocean acidification may influence coral reef organisms and coral reef communities. We argue that it is unclear as to how, and to what extent, ocean acidification will influence calcium carbonate calcification and dissolution, and affect changes in community structure of present-day coral reefs. It is critical to evaluate the extent to which the metabolism of present-day reefs is influenced by mineral saturation states, and to determine a threshold saturation state at which coral communities cease to function as reefs.
\end{abstract}

KEY WORDS: Ocean acidification $\cdot$ Climate change $\cdot$ Coral reefs $\cdot$ Biogeochemistry

\section{INTRODUCTION}

Ocean acidification is the progressive increase in hydrogen ions $\left(\mathrm{H}^{+}\right)$in the world's oceans as a result of rising partial pressure of atmospheric carbon dioxide $\left(\mathrm{CO}_{2}\right)$, i.e. a decrease in seawater $\mathrm{pH}$, where $\mathrm{pH}=$ $-\log _{10}\left[\mathrm{H}^{+}\right]$; see Dickson (1984) for a review of the different $\mathrm{pH}$ scales for seawater. As atmospheric carbon dioxide has increased as a result of the burning of fossil fuels, increasing amounts of $\mathrm{CO}_{2}$ have entered the ocean and reacted with water (Sabine et al. 2004). When $\mathrm{CO}_{2}$ gas reacts with water, carbonic acid is formed and the ocean becomes progressively more acidic $\left(\mathrm{CO}_{2}+\mathrm{H}_{2} \mathrm{O}=\mathrm{H}_{2} \mathrm{CO}_{3}=\mathrm{HCO}_{3}{ }^{-}+\mathrm{H}^{+}=\mathrm{CO}_{3}{ }^{2-}+\right.$ $2 \mathrm{H}^{+}$), driving the $\mathrm{CO}_{2}$ chemical equilibrium toward $\mathrm{CO}_{2}$ and $\mathrm{HCO}_{3}{ }^{-}$, reducing $\mathrm{CO}_{3}{ }^{2-}$, the carbonate ion.

Several oceanic feedback loops buffer $\mathrm{pH}$, but presently these buffering mechanisms are considered relatively small, and will not counteract the falling $\mathrm{pH}$ over the next 100 yr (Andersson et al. 2006, 2007). $\mathrm{CO}_{2}$ gas influx and efflux between oceans and atmosphere are large terms in the overall oceanic carbon budget, with substantial errors (Houghton 2007). Nevertheless, the scientific community has observed an estimated decrease of $0.1 \mathrm{pH}$ units in the surface ocean in the last $100 \mathrm{yr}$ and current trends in atmospheric $\mathrm{CO}_{2}$ partial pressure project a further change of 0.3 to $0.4 \mathrm{pH}$ units over the next 100 yr (Sabine et al. 2004, Orr et al. 2005). The above calculations are based on a stable total alkalinity. Thus, over the next $100 \mathrm{yr}, \mathrm{CO}_{2}$ gas dissolved in tropical oceans is expected to increase 200 to $250 \%$, and $\mathrm{CO}_{3}{ }^{2-}$ is expected to decrease 35 to $50 \%$, reducing the saturation state of seawater with respect to calcium carbonate minerals (Orr et al. 2005).

The saturation state of seawater for a mineral $(\Omega)$ is a measure of the thermodynamic potential for the mineral to form or to dissolve; specifically it is the product of the concentrations (or activities) of the reacting ions that form the mineral $\left(\mathrm{Ca}^{2+}\right.$ and $\left.\mathrm{CO}_{3}{ }^{2-}\right)$, divided by the product of the concentrations of those ions when the mineral is at equilibrium $\left(K_{\mathrm{sp}}\right)$, that is, when the mineral is neither forming nor dissolving:

$$
\Omega=\frac{\left[\mathrm{Ca}^{2+}\right]\left[\mathrm{CO}_{3}^{2-}\right]}{K_{\mathrm{sp}}}
$$

when $\Omega>1.0$, the formation of the mineral is thermodynamically favorable; when $\Omega<1.0$, the dissolution of the mineral is favorable. Aragonite $\Omega\left(\Omega_{\text {arag }}\right)$ of surface seawater is expected to decrease throughout the tropics from the present-day values of 3 to 3.5 to 2 to 2.5 in $100 \mathrm{yr}$; and the ratio of dissolved $\mathrm{CO}_{2}$ gas to $\mathrm{CO}_{3}{ }^{2-}$ will increase by a factor of 4 (Orr et al. 2005). 
Based on principles of thermodynamics, the rate of formation of carbonates is positively correlated to $\Omega$; this pervading principle has been central to biological and chemical production, distribution and dissolution of carbonates in the oceans (Feely et al. 2004, Zachos et al. 2005), as well as tropical coastal seas (Broecker et al. 2001, Morse et al. 2003). Thus, there has been a long standing observation that the distribution of coral reefs is highly correlated to $\Omega_{\text {arag }}$ in the ocean, implying that the limits of coral reef formation may not be controlled solely by temperature, light, salinity or substrate availability (Grigg 1982, Smith \& Buddemeier 1992, Buddemeier \& Fautin 1996). Further investigations have explicitly stated that $\Omega_{\text {arag, }}$ together with light and temperature, set boundaries for coral reef biogeography (Kleypas et al. 1999a). The present paper will discuss the effects of ocean acidification on coral reefs from the above estimates of changes in $\mathrm{pH}$ and $\mathrm{CO}_{2}$ equilibria.

There are 2 possible major effects of the changing ratio of $\mathrm{CO}_{2}$ gas to $\mathrm{CO}_{3}{ }^{2-}$ on coral reefs: (1) changes in organism and community rates of calcification and dissolution, and (2) changes in relative metabolism of autotrophs, cyanobacteria and bacteria, which in turn have the potential to alter community structure and biogeochemical cycles.

\section{CALCIFICATION}

\section{Impact of decreasing saturation state on organismic calcification rates}

Saturation state has been shown to affect growth in calcifying green algae, crustose coralline algae and corals (reviewed by Kleypas \& Langdon 2006). The first estimates of total pre-industrial to 2100 reef calcification decreases were 17 to $40 \%$ (Gattuso et al. 1999, Kleypas et al. 1999b). With increasing sea surface temperature (SST) and reduced $\Omega$, there is concern that coral reefs may soon reach a threshold of 'no return', losing corals and other calcifiers, becoming dead carbonate platforms covered in macro-algae (HoeghGuldberg et al. 2007). Several studies have observed thresholds of coral growth and coral reef development at $\Omega=3.0$ to 3.3 based on the geographic distribution of coral reefs (Kleypas et al. 1999b, Guinotte et al. 2003, Hoegh-Guldberg et al. 2007, Buddemeier et al. 2008). Considering the enormity of the postulated impact, it is crucial to continue research into how $\Omega$ influences the growth of a variety of different taxa. There are many questions remaining to be answered, however, before thresholds of growth/calcification can be established. For example, responses of coral to $\Omega$ vary between experiments (see Langdon \& Atkinson 2005, their
Fig. 9). Thus, we suggest several avenues of research (next subsections), all towards understanding how $\Omega$ affects the basic calcification mechanism, and trying to establish some confidence in a particular value of $\Omega$ at which reefs might degrade.

\section{Saturation state versus co-varying parameters}

Although coral calcification is unquestionably influenced by $\Omega$, it is not clear whether calcification is also responding to other co-varying parameters, such as $\mathrm{pH}, \mathrm{HCO}_{3}{ }^{-}$or $\mathrm{pCO}_{2}$. For example, in some cultures of Emiliania huxleyi (a carbon-limited coccolithophore) grown under high $\mathrm{pCO}_{2}$ and high nutrients, inorganic and organic carbon production and cell size were enhanced despite the decrease in calcite $\Omega$ ( $\left.\Omega_{\text {calc }}\right)$ (Iglesias-Rodriguez et al. 2008). Thus, concerns have arisen regarding experiments using only $\mathrm{HCl}$ to decrease $\mathrm{pH}$, without further addition of bicarbonate to offset the drop in total alkalinity. Achieving reduced $\mathrm{pH}$ by $\mathrm{CO}_{2}$ bubbling or by combinations of both acid and bicarbonate to maintain constant alkalinity, is thought to better mimic future $\mathrm{CO}_{2}$ scenarios.

The extent to which increased dissolved inorganic carbon (DIC) can counteract the effect of decreasing $\Omega$ on coral calcification is considered moderate (Kleypas \& Langdon 2006) because (1) $\mathrm{HCO}_{3}{ }^{-}$(the substrate for photosynthesis) will increase only about $14 \%$ under doubled $\mathrm{pCO}_{2}$ conditions; (2) increased $\mathrm{pCO}_{2}$ is usually assumed to have little or no effect on photosynthesis (Reynaud et al. 2003, Schneider \& Erez 2006); (3) it is not evident that an increase in photosynthesis will necessarily lead to increased calcification (discussed by Kleypas \& Langdon 2006). Some studies have, however, shown an enhancement of coral growth (calcification) after an increase in DIC (Marubini \& Thake 1999, Schneider \& Erez 2006, Herfort et al. 2008), suggesting that the ambient DIC concentration of seawater may limit the calcification rates of hermatypic corals. In some experiments, an increase in DIC concentration also resulted in an increase in photosynthesis (Herfort et al. 2008, Marubini et al. 2008). Marubini et al. (2008) recently reported that Stylophora pistillata nubbins grew faster in bicarbonate-enriched seawater independent of $\mathrm{pH}$ conditions ( $\mathrm{pH} 7.6$ to 8.2). Thus, it is essential that studies of coral calcification and acidification report details of the DIC parameters and not only $\mathrm{pH}$.

\section{Mechanism of coral calcification}

Inadequate understanding of the mechanism of coral calcification limits our ability to provide an accurate prediction of the effect of increasing atmospheric $\mathrm{CO}_{2}$ 
(Gattuso et al. 1999). It is still not well understood how the elemental composition and physical chemistry of the external environment interacts with biological control under different saturation state conditions (Cohen et al. 2006). In hermatypic corals, the supply of $\mathrm{Ca}^{2+}$, as well as $\mathrm{HCO}_{3}{ }^{-}$derived from host tissue respiration (via a carbonic anhydrase), are biologically controlled (Allemand et al. 2004). Geochemical models (e.g. Adkins et al. 2003, Gaetani \& Cohen 2006, Sinclair \& Risk 2006), however, have considered diffusion of $\mathrm{CO}_{2}$ across the calicoblastic epithelium, and passive entry of seawater, e.g. through pericellular channels (see Cohen \& McConnaughey 2003). The level of control of skeletal organic compounds (the organic matrix synthesized by the calicoblastic cells) over the chemistry and growth of coral skeleton is also a topic of debate (Meibom et al. 2007). Thus, considering these models of coral calcification, there is still some question as to why external concentrations of carbonate should have such a strong effect on calcification.

Even though calcification observed under light is greater than that under dark conditions (reviewed by Gattuso et al. 1999), the relationship between calcification and $\Omega$ appears to have a similar slope in both the light and the dark (Ohde \& Hossain 2004, Schneider \& Erez 2006). One interpretation of this evidence is that a simple diffusion pathway must exist, possibly revealing an increase in the flux of bicarbonate from enhanced light respiration (see discussion in Marubini et al. 2008). Based upon morphological evidence, the calicoblastic cell layer is regarded as a 'tight' epithelium, reducing the ability of $\mathrm{Ca}^{2+}$ and $\mathrm{CO}_{3}{ }^{2-}$ to diffuse away via a paracellular route (Clode \& Marshall 2002). An increase in outward diffusion of carbonate when external carbonate is low cannot be dismissed, however. A decrease in $\mathrm{pH}$ may affect different cellular processes, e.g. anionic permeability (Gattuso et al. 1999), or $\mathrm{pH}$ regulation during the calcification process (Marubini et al. 2008). Indeed, $\mathrm{H}^{+}$ions produced during calcium carbonate precipitation $\left(\mathrm{HCO}_{3}{ }^{-}+\mathrm{Ca}^{2+} \rightarrow\right.$ $\mathrm{CaCO}_{3}+\mathrm{H}^{+}$) are removed from the calcification sites by an energy-dependent carrier $\left(\mathrm{Ca}^{2+}\right.$-ATPase), thereby increasing $\Omega$ (see reviews by Cohen \& McConnaughey 2003, Allemand et al. 2004).

Studies are needed that focus on the physico-chemical characteristics of the sub-calicoblastic space under different saturation state conditions, or on actual morphological features connecting the calicoblastic cells to seawater. For example, Tambutté et al. (2007) report that some tissues calcifying at the highest rates in Stylophora pistillata consist only of ectodermal cell-layers separated by mesoglea. It would be informative to determine whether these observations give more clues about the mechanism of coral calcification. The magnitude of the response to low $\Omega$ seems to be constant between coral species (Marubini et al. 2003). There should be, however, further effort to compare taxa with differing sensitivities to external saturation state.

\section{Interaction with other parameters}

Hermatypic coral calcification is a strong function of light (Gladfelter 1984, Allemand et al. 2004), shows temperature optima (Marshall \& Clode 2004), and is affected by nutrients (Tanaka et al. 2007) and particulate feeding (Houlbrèque et al. 2003), yet there are no studies on the effects of $\Omega$ that adequately control all 4 of these variables. The magnitude of the effect of $\Omega$ on calcification increases with increasing light and temperature (Marubini et al. 2001, Reynaud et al. 2003). When nutrients are added to the waters surrounding corals, however, the corals become less sensitive to $\Omega$ (Atkinson et al. 1995, Langdon \& Atkinson 2005, selected data from their Fig. 5), perhaps because symbiotic dinoflagellates (Symbiodinium spp.) enhance calcification by providing the biochemical precursors of the organic matrix (Muscatine et al. 2005). Nutrient loading, typical of that seen in the field, increased the $\Omega$ threshold for calcification of a mixed coral community from 1.5 to 1.0 (recent experiments, unpublished, Fig. 1). This coral community dominates in Hawaii, and calcifies at $\Omega<3.0$,

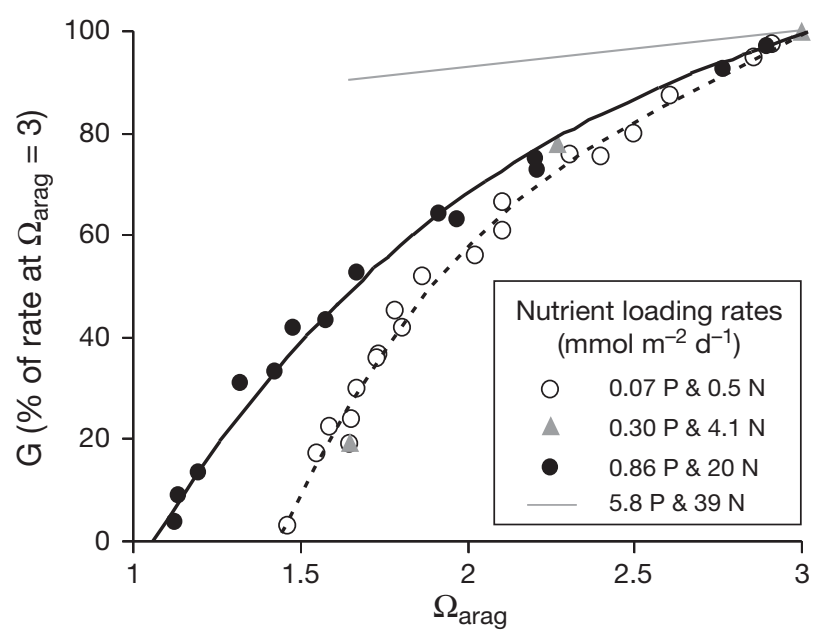

Fig. 1. Effect of nutrient loading on coral calcification rate (G). Coral communities $\left(0.3 \mathrm{~m}^{2}\right.$; Montipora capitata, Porites compressa and Pocillopora damicornis) were placed in a wave flume with equal light, gross primary production, water motion and initial aragonite saturation state $\left(\Omega_{\text {arag }}\right)$. Nutrient loading was varied from extremely low values to those representative of field conditions. The closed black circles (black line) represent communities that were given natural nutrient loading rates and the open circles (dashed line) are low nutrient conditions. The grey triangles and the grey line are data from Langdon \& Atkinson (2005) for a nutrient loading experiment with the same species. Data are normalized to $\Omega_{\text {arag }}=3.0$ for intercomparison. The nutrient loading rates are in the key 
contrary to calcification threshold values stated in Buddemeier et al. (2008). Also, nutrient loading as particles often increases skeletal growth (Bongiorni et al. 2003, Houlbrèque et al. 2003, Shafir et al. 2006), but no study to date has assessed the possible interactions between feeding and $\Omega$. It is our suspicion that many experiments have been performed in low light, relatively starved conditions, with extremely low pH. Future studies should report nutrient and particulate loading as well as optimal light intensities in order to assess the nutritional status of the corals. More research is needed on the effects of $\Omega$, under natural field conditions, for a variety of coral reef calcifying organisms (Schneider \& Erez 2006). These are difficult experiments and require improved facilities to control the environmental variables. Data on a variety of taxa may then be synthesized to present a threshold at which corals do not grow (and at which changes in community structure may prove to be unavoidable).

Anthony et al. (2008) reported increased sensitivity of corals to bleaching as a result of acidified seawater conditions. One possible explanation for the loss of zooxanthellae is that high $\mathrm{CO}_{2}$ reduces the efficiency of $\mathrm{Ru}$ BisCO (maximum activity at $\mathrm{pH}$ 9) to react with oxygen radicals, leaving more oxygen radicals to stimulate bleaching in coral tissue. Other interpretations may relate to the greater efficiency of Symbiodinium spp. under carbon-rich conditions, and the resulting compensatory reduction in symbiont number (i.e. bleaching). These observations are contrary to published experiments and observations in which corals were grown at very low $\mathrm{pH}$ (7.2 to 7.8) without bleaching (Atkinson et al. 1995, Marubini \& Atkinson 1999). Clearly, there appears to be a diversity of responses from corals that requires further investigation.

\section{Community calcification}

Are communities of corals showing effects of $\Omega$ in the field? This question was addressed by Kinsey in the 1970s. He tried to find some latitudinal variation in calcification, correlating with mean temperature and $\Omega$, and instead developed the concept of standard metabolism and reef zonation, controlled largely by hydrodynamics (Kinsey 1979, 1985). Kinsey made a strong case that community structure and corresponding zonation gave characteristic rates of calcification (reviewed in Atkinson \& Falter 2003). Calcification rates vary by an order of magnitude within a coral reef, from areas that have rich coral communities to other areas that are flat and just consist of sand. The higher the 3-dimensional relief of the benthic community, the greater is primary productivity and calcification. In general, daily calcification rates are about 15 to $20 \%$ of the gross primary production (Kinsey 1985, Gattuso et al. 1999). Thus, coral reef calcification and coral calcification are strongly a function of gross productivity, even at the scale of a polyp (Al-Horani et al. 2005). It is now assumed that reef calcification is proportional to both gross primary productivity and $\Omega$ (Nakamura \& Nakamori 2007), but it is not clear to what extent $\Omega$ actually affects a whole reef. When a lack of storm damage allows the maintenance of high productivity community structure, by lack of storm damage, rising sea-level and warming temperatures may be more important than small changes in $\Omega$. These issues are clearly important and should be the focus for future research.

Evidence of an effect of $\Omega$ on community calcification in the field is still scarce. In a seasonal study, calcification was correlated to $\Omega$ (Silverman et al. 2007), however, $\Omega$ was also correlated to seasonal changes in temperature, light and nutrients, and it was difficult to identify the forcing parameter. The model for calculating calcification was also based on salinity changes between nearshore and offshore sampling sites and made all variables dependent. Yates \& Halley (2006), using a large closed chamber on a reef flat in Hawaii, reported rates of dissolution and calcification as a function of $\Omega$. Their results were quite variable and it was difficult to set a single $\Omega$ threshold value. They showed an enhancement of calcification at high $\Omega$, but it is not clear in their study whether calcification was responding to increased productivity or elevated $\Omega$ within the chamber. Studies on growth of large Porites spp. in the Great Barrier Reef show both inter-decadal increases and decreases in calcification per surface area (Cooper et al. 2008). These data are difficult to interpret on an ecological basis (see Lough 2008, this Theme Section). As a single coral head grows larger (more convoluted and oblique to the light field) light absorption per area decreases (Stambler \& Dubinsky 2005). This effect probably reduces calcification per surface area of the coral, even though calcification per planar area of reef may be increasing. There is large variability in environmental light quantity and quality due to daylength, cloud-cover and water turbidity, thus changes in calcification rate per surface area of coral tissue can change daily, seasonally, and even within decades, making it difficult to link coral growth to changes in temperature and $\Omega$.

One of the key issues underlying our understanding of the impact of ocean acidification is how to evaluate the impact of $\Omega$ on reef calcification under field conditions. Field studies must obviously involve measurement of light, productivity and respiration. We suggest a comprehensive experiment involving several reefs with different $\Omega \mathrm{s}$, to determine how the relationship between primary productivity and calcification is 
affected or controlled by temperature, $\Omega$ and nutrient input. If calcification is decreasing with respect to $\Omega$, then on a large reef scale, independent of detailed community structure, we should be capable of producing a derivative calcification ratio, G:P (slope of calcification $=f($ gross primary production) $)$ related to $\Omega$. With present technology, it is possible to evaluate calcification and productivity on large reef scales, combining all zones and communities by using a combination of in situ measurements, hydrodynamic models and remote sensing products. In situ chemical measurements and accurate hydrodynamic models (e.g. Lowe et al. 2008) can be used to measure calcification rates of large areas of coral reefs and remote sensing products are being developed for reef productivity (Hochberg \& Atkinson 2007).

\section{Dissolution of calcium carbonates}

The solubilities of high-Mg carbonates from natural reef environments are not well determined (Morse et al. 2006). These carbonates are abundant on reefs and form a significant part of the framework, thus, it is important to determine the $\Omega$ or $\mathrm{pH}$ at which these minerals will dissolve. There are conflicting views as to the extent to which the $\Omega$ of overlying seawater can influence dissolution in sediments. Manzello et al. (2008) showed increased dissolution in the Eastern Tropical Pacific, suggesting that this is from low-pH upwelled water, while Andersson et al. (2007) showed high-Mg calcites were dissolving in Bermuda from natural changes in $\Omega$, but with little difference compared to other places; they pointed out the influence of naturally low $\mathrm{pH}$ in sediments. A primary direction of research is to understand the dissolution of these carbonates in a natural system.

Bio-erosion by endolithic phototrophs, which inhabit every available carbonate substrate, should also be better quantified. The endolithic chlorophyte Ostreobium quekettii increased its depth of penetration under $\mathrm{pCO}_{2}$ of $750 \mu \mathrm{atm}$ (Tribollet et al. in press), suggesting increased biogenic carbonate dissolution under high $\mathrm{pCO}_{2}$.

\section{EFFECTS ON BIOGEOCHEMICAL CYCLES, AND COMMUNITY STRUCTURE SHIFTS}

\section{Carbon and nutrients}

It is very likely that increased $\mathrm{CO}_{2}$ will alter the relative growth and efficiency of different groups of organisms (Phytoplankton, Riebesell et al. 2007; Cyanophytes, Levitan et al. 2007; Seagrass, Palacios \&
Zimmerman 2007). For example, the net photosynthetic rates of epilithic coralline algae decreased in 750 ratm $\mathrm{pCO}_{2}$, while endolithic communities remained constant (Tribollet et al. 2006). Increased $\mathrm{pCO}_{2}$ may stimulate growth of algae that do not have carbon-concentrating mechanisms (Kaplan \& Reinhold 1999). It is usually assumed that macro-algae as a group will exhibit little photosynthetic response to increasing $\mathrm{pCO}_{2}$, because most of them possess carbon-concentrating mechanisms. However, some species are carbon-limited with the current levels of dissolved inorganic carbon in seawater (see references in Zou 2005). It is also suggested that the energy used for carbon-concentrating mechanisms can be used for growth when $\mathrm{pCO}_{2}$ is high (Levitan et al. 2007).

Faster growth under high $\mathrm{pCO}_{2}$ may increase $\mathrm{C}: \mathrm{N}: \mathrm{P}$ ratios of macro-algae, further providing relatively low quality food to herbivores. Uptake of phosphate and nitrogen compounds are generally under hydrodynamic control (Atkinson \& Falter 2003), thus it is unlikely that increased net production would stimulate increased nitrogen uptake. If this response occurs, then coral reefs may shift to higher export of organic matter, deposition and bacteria remineralization in back-reef areas, creating zones of anoxia. There may also be more export of dissolved organic matter. This scenario would suggest less carbon of higher quality moving up and through the foodweb. On the other hand, it is also quite possible that increased growth of nitrogen fixing cyanobacteria may enhance nitrogen fixation (Levitan et al. 2007). Nitrogen fixation can be a large source of nitrogen to some reefs, thus an increase in nitrogen fixation may further enhance photosynthetic efficiencies and net production. There may be major shifts in the biogeochemistry of reefs, yet we know very little how nutrient cycles are presently coupled to carbon cycles, nor how different groups of algae compete for scarce nutrients.

\section{Community structure}

The recruitment rate and growth of crustose coralline algae is severely inhibited under elevated $\mathrm{pCO}_{2}$, suggesting changes in benthic community structure may occur owing to the impact of ocean acidification on recruitment and competition for space (Kuffner et al. 2008, Jokiel et al. 2008). At a shallow coastal site in the Mediterranean where vents of volcanic carbon dioxide reduce seawater $\mathrm{pH}(\mathrm{pH} 7.8$ to 7.9), non-calcareous algae proved to be resilient to naturally high $\mathrm{pCO}_{2}$, replacing typical rocky shore communities ( $\mathrm{pH} 8.1$ to 8.2 ) with $>60 \%$ cover of Corallinaceae (Hall-Spencer et al. 2008). In the mesocosm experiment performed by Jokiel et al. (2008), however, 
the space made available from the reduction in crustose coralline algae cover was not colonized by noncalcifying algae (e.g. turfs). Any advantage of noncalcifying algae under high $\mathrm{pCO}_{2}$ could be offset by increased herbivory (Jokiel et al. 2008). With reductions in crustose coralline algae, coral recruitment may be affected (Hoegh-Guldberg et al. 2007), but coral spawning and recruitment were not affected under elevated $\mathrm{pCO}_{2}$ (Jokiel et al. 2008). Some scleractinian coral species were also found to survive from decalcification as polyps in the laboratory, including normal gametogenesis (Fine \& Tchernov 2007).

These experiments are just the beginning to our understanding of the complex response of coral reefs to ocean acidification. Undoubtedly, ocean acidification will create major shifts in community structure that will certainly affect communities of grazers. We suggest developing an enclosed high- $\mathrm{pCO}_{2}$ natural coral reef mesocosm, in which synergistic effects of different organisms responding to changes in water chemistry can be observed. In this way, organismal calcification, growth and competition can be compared with changes in community structure. Also direct measurements and observations of calcium carbonate mineral dissolution in sediments can be achieved.

\section{RECOMMENDATIONS FOR RESEARCH}

A coordinated research effort is required to understand and ascertain whether a decrease in $\Omega$ will alter the community structure and function of coral reefs. It is now accepted that dissolved inorganic carbon species are very important chemical parameters of the function of a variety of key taxa comprising coral reefs, but our understanding is limited and quantification almost non-existent. The next challenge is to understand how both organismal and community metabolism interact with dissolved inorganic carbon chemistries. This effort will require a new generation of experimental facilities and instrumentation for reefs. Some suggestions for research directions are to:

(1) continue to evaluate the effects of bicarbonate and carbonate ions on growth and calcification of key taxa, under environmental realistic conditions of light, temperature, nutrients and dissolved inorganic carbon;

(2) study the morphology of carbonate calcification, looking for the structural detail at the sites of calcification;

(3) develop an improved model for coral calcification;

(4) conduct studies on high-Mg carbonate solubility constants for naturally occurring carbonates on coral reefs;

(5) develop several natural coral reef mesocosms, complete with sediments, to observe whole system changes and community structure competition:
(6) develop a program to evaluate the relationships between community metabolism and calcification at several coral reefs with different $\Omega$ s, and test whether present naturally-varying $\Omega$ drives community calcification rates;

(7) expand efforts in monitoring basic $\mathrm{CO}_{2}$ parameters on a number of coral reefs worldwide, in conjunction with basic community structure data. These do not have to be continuous but must span decades;

(8) study effects of $\mathrm{pH}$ on a variety of algae, including endoliths, as well as key species of nitrogen fixing cyanobacteria.

\section{LITERATURE CITED}

Adkins JF, Boyle EA, Curry WB, Lutringer A (2003) Stable isotopes in deep-sea corals and a new mechanism for 'vital effects'. Geochim Cosmochim Acta 67:1129-1143

Al-Horani FA, Ferdelman T, al-Moghrabi SM, de Beer D (2005) Spatial distribution of calcification and photosynthesis in the scleractinian coral Galaxea fascicularis. Coral Reefs 24:173-180

Allemand D, Ferrier-Pagès $C$, Furla $P$, Houlbrèque $F$ and others (2004) Biomineralisation in reef-building corals: from molecular mechanisms to environmental control. C R Palevol 3:453-467

> Andersson AJ, Mackenzie FT, Lerman A (2006) Coastal ocean $\mathrm{CO}_{2}$-carbonic acid-carbonate sediment system of the Anthropocene. Global Biogeochem Cycles 20:GB1S92, doi:10.1029/2005GB002506

Andersson AJ, Bates NR, Mackenzie FT (2007) Dissolution of carbonate sediments under rising $\mathrm{pCO}_{2}$ and ocean acidification: observations from Devil's Hole, Bermuda. Aquat Geochem 13:237-264

> Anthony KRN, Kline DI, Diaz-Pulido G, Dove S, HoeghGuldberg O (2008) Ocean acidification causes bleaching and productivity loss in coral reef builders. Proc Natl Acad Sci USA 105:17442-17446

Atkinson MJ, Falter JL (2003) Coral reefs. In: Black K, Shimmield G (eds) Biogeochemistry of marine systems. CRC Press, Boca Raton, FL, p 40-64

Atkinson MJ, Carlson B, Crow JB (1995) Coral growth in high-nutrient, low-pH seawater: a case-study in coral grown in the Waikiki aquarium, Honolulu, Hawaii. Coral Reefs 14:215-223

> Bongiorni L, Shafir S, Angel D, Rinkevich B (2003) Survival, growth and reproduction of two hermatypic corals subjected to in situ fish farm nutrient enrichment. Mar Ecol Prog Ser 253:137-144

Broecker WS, Langdon C, Takahashi T, Peng TH (2001) Factors controlling the rate of $\mathrm{CaCO}_{3}$ precipitation on Great Bahama. Global Biogeochem Cycles 15:589-596

Buddemeier RW, Fautin DG (1996) Saturation state and the evolution and biogeography of symbiotic calcification. Bull Inst Océanogr (Monaco) 14:23-32

Buddemeier RW, Jokiel P, Zimmerman KM, Lane DR, Carey JM, Bohling GC, Martinich JA (2008) A model tool to evaluate regional coral reef responses to changes in climate and ocean chemistry. Limnol Oceanogr Methods 6:395-411

Clode PL, Marshall AT (2002) Low temperature FESEM of the calcifying interface of a scleractinian coral. Tissue Cell 34:187-198 
Cohen AL, McConnaughey TA (2003) Geochemical perspectives on coral mineralization. In: Dove PM, Weiner S, deYoreo JJ (eds) Biomineralization. Rev Mineral Geochem 54: 151-187

Cohen AL, Gaetani GA, Lundälv T, Corliss BH, George RY (2006) Compositional variability in a cold-water scleractinian, Lophelia pertusa: new insights into 'vital effects'. Geochem Geophys Geosyst 7:Q12004, doi: 10.1029/2006GC001354

Cooper TF, De'ath G, Fabricius KE, Lough JM (2008) Declining coral calcification in massive Porites in two nearshore regions of the northern Great Barrier Reef. Glob Change Biol 14:529-538

$>$ Dickson AG (1984) pH scales and proton-transfer reactions in saline media such as sea water. Geochim Cosmochim Acta 48:2299-2308

Feely RA, Sabine CL, Lee K, Berelson W, Kleypas J, Fabry VJ, Millero FJ (2004) Impact of anthropogenic $\mathrm{CO}_{2}$ on the $\mathrm{CaCO}_{3}$ system in the oceans. Science 305:362-366

Fine M, Tchernov D (2007) Scleractinan coral species survive and recover from decalcification. Science 315:1811

Gaetani GA, Cohen AL (2006) Element partitioning during precipitation of aragonite from seawater: a framework for understanding paleoproxies. Geochim Cosmochim Acta 70:4617-4634

Gattuso JP, Allemand D, Frankignoulle M (1999) Photosynthesis and calcification at cellular, organismal and community levels in coral reefs: a review on interactions and control by carbonate chemistry. Am Zool 39:160-183

> Gladfelter EH (1984) Skeletal development in Acropora cervicornis 3. A comparison of monthly rates of linear extension and calcium carbonate accretion measure over a year. Coral Reefs 3:51-57

Grigg RW (1982) Darwin Point: A threshold for atoll formation. Coral Reefs 1:29-34

Guinotte JM, Buddemeier RW, Kleypas JA (2003) Future coral reef habitat marginality: temporal and spatial effects of climate change in the Pacific basin. Coral Reefs 22: 551-558

Hall-Spencer JM, Rodolfo-Metalpa R, Martin S, Ransome E and others (2008) Volcanic carbon dioxide vents show ecosystem effect of ocean acidification. Nature 454:96-99

Herfort L, Thake B, Tauber I (2008) Bicarbonate stimulation of calcification and photosynthesis in two hermatypic corals. J Phycol 44:91-98

Hochberg E, Atkinson MJ (2008) Coral reef benthic productivity based on optical absorptance and light-use efficiency. Coral Reefs 27:49-59

Hoegh-Guldberg O, Mumby PJ, Hooten AJ, Steneck RS and others (2007) Coral reefs under rapid climate change and ocean acidification. Science 318:1737-1742

Houghton RA (2007) Balancing the global carbon budget. Annu Rev Earth Planet Sci 35:313-347

Houlbrèque F, Tambutte E, Ferrier-Pagès C (2003) Effect of zooplankton availability on the rates of photosynthesis, and tissue and skeletal growth in the sclearctinian coral Stylophora pistillata. J Exp Mar Biol Ecol 296:145-166

Iglesias-Rodriguez MD, Halloran PR, Rickaby REM, Hall IR and others (2008) Phytoplankton calcification in a high$\mathrm{CO}_{2}$ world. Science 320:336-340

Jokiel PL, Rodgers KS, Kuffner IB, Andersson AJ, Cox EF, Mackenzie FT (2008) Ocean acidification and calcifying reef organism: a mesocosm investigation. Coral Reefs $27: 473-483$

Kaplan A, Reinhold L (1999) $\mathrm{CO}_{2}$ concentrating mechanisms in photosynthetic microorganisms. Annu Rev Plant Physiol Plant Mol Biol 50:539-570
Kinsey DW (1979) Carbon turnover and accumulation by coral reefs. PhD thesis, University of Hawaii, Honolulu

Kinsey DW (1985) Metabolism, calcification and carbon production: system level studies. Proc 5th Int Coral Reef Congr 4:505-526

Kleypas JA, Langdon C (2006) Coral reefs and changing seawater chemistry. In: Phinney JT, Hoegh-Guldberg O, Kleypas J, Skirving W, Strong A (eds) Coral reefs and climate shange: science and management. AGU Monograph Series, Coast Estuar Stud 61:73-110

Kleypas JA, McManus J, Menez L (1999a) Using environmental data to define reef habitat: Where do we draw the line? Am Zool 39:146-159

Kleypas JA, Buddemeier RW, Archer D, Gattuso JP, Langdon C, Opdyke BN (1999b) Geochemical consequences of increased atmospheric $\mathrm{CO}_{2}$ on coral reefs. Science 284: $118-120$

Kuffner IB, Andersson AJ, Jokiel PL, Rodgers KS, Mackenzie FT (2008) Decreased abundance of crustose coralline algae due to ocean acidification. Nature Geocscience 1: 114-117

> Langdon C, Atkinson MJ (2005) Effects of elevated $\mathrm{pCO}_{2}$ on photosynthesis and calcification of corals and interactions with seasonal change in temperature/irradiance and nutrient enrichment. J Geophys Res 110:C09S07, doi:10.1029/2004JC002576

> Levitan O, Rosenberg G, Setlik I, Setlikova E and others (2007) Elevated $\mathrm{CO}_{2}$ enhances nitrogen fixation and growth in the marine cyanobacterium Trichodesmium. Glob Change Biol 13:531-538

> Lough JM (2008) Coral calcification from skeletal records revisited. Mar Ecol Prog Ser 373:257-264

Lowe RJ, Falter JL, Monismith SG, Atkinson MJ (2008) Wavedriven circulation of a coastal reef-lagoon system. J Phys Oceanogr (in press), doi:10.1175/2008JPO3958.1

Manzello DP, Kleypas JA, Budd DA, Eakin CM, Glynn PW, Langdon C (2008) Poorly cemented coral reefs of the eastern tropical Pacific: possible insights into reef development in a high- $\mathrm{CO}_{2}$ world. Proc Natl Acad Sci USA 105:10450-10455

Marshall AT, Clode P (2004) Calcification rate and the effect of temperature in a zooxanthellate and an azooxanthellate scleractinian reef coral. Coral Reefs 23:218-224

Marubini F, Atkinson MJ (1999) Effects of lowered pH and elevated nitrate on coral calcification. Mar Ecol Prog Ser 188:117-121

Marubini F, Thake B (1999) Bicarbonate addition promotes coral growth. Limnol Oceanogr 44:716-720

Marubini F, Barnett H, Langdon C, Atkinson MJ (2001) Dependence of calcification on light and carbonate ion concentration for the hermatypic coral Porites compressa. Mar Ecol Prog Ser 220:153-162

> Marubini F, Ferrier-Pagès C, Cuif JP (2003) Suppression of skeletal growth in scleractinian corals by decreasing ambient carbonate-ion concentration: a cross-family comparison. Proc R Soc Lond B Biol Sci 270:179-184

> Marubini F, Ferrier-Pagès C, Furla P, Allemande D (2008) Coral calcification responds to seawater acidification: a working hypothesis towards a physiological mechanism. Coral Reefs 27:491-499

> Meibom A, Mostefaoui S, Cuif JP, Dauphin Y, Houlbrèque F, Dunbar R, Constantz B (2007) biological forcing controls the chemistry of reef-building coral skeleton. Geophys Res Lett 34:L02601, doi:10.1029/2006GL028657

Morse JW, Gledhill DK, Millero FJ (2003) $\mathrm{CaCO}_{3}$ precipitation kinetics in the waters from the Grand Bahama Bank: implication for the relationship between bank hydro- 
chemistry and whitings. Geochim Cosmochim Acta 67: 2819-2826

Morse JW, Andersson AJ, Mackenzie FT (2006) Initial responses of carbonate-rich shelf sediments to rising atmospheric $\mathrm{CO}_{2}$ and 'ocean acidification': role of high Mg-calcites. Geochim Cosmochim Acta 70:5814-5830

Muscatine L, Goiran C, Land L, Jaubert J, Cuif JP, Allemand D (2005) Stable isotopes $\left(\delta^{13} \mathrm{C}\right.$ and $\left.\delta^{15} \mathrm{~N}\right)$ of organic matrix from coral skeleton. Proc Natl Acad Sci USA 102: $1525-1530$

Nakamura T, Nakamori T (2007) A geochemical model for coral reef formation. Coral Reefs 26:741-755

Ohde S, Hossain MMM (2004) Effect of $\mathrm{CaCO}_{3}$ (aragonite) saturation state of seawater on calcification of Porites spp. coral. Geochem J 38:613-621

$>$ Orr JC, Fabry VJ, Aumont O, Bopp L and others (2005) Anthropogenic ocean acidification over the twenty-first century and its impact on calcifying organisms. Nature 437:681-686

Palacios SL, Zimmerman RC (2007) Response of eelgrass Zostera marina to $\mathrm{CO}_{2}$ enrichment: possible impacts of climate change and potential for remediation of coastal habitats. Mar Ecol Prog Ser 344:1-13

Reynaud S, Leclercq N, Romaine-Lioud S, Ferrier-Pagès $C$, Jaubert J, Gattuso JP (2003) Interacting effects of $\mathrm{CO}_{2}$ partial pressure and temperature on photosynthesis and calcification in a scleractinian coral. Glob Change Biol 9:1660-1668

Riebesell U, Schulz KG, Bellerby RGJ, Botros M and others (2007) Enhanced biological carbon consumption in a high $\mathrm{CO}_{2}$ ocean. Nature 450:545

Sabine CL, Feely RA, Gruber N, Key RM and others (2004) The oceanic sink for anthropogenic $\mathrm{CO}_{2}$. Science 305: 367-371

Schneider K, Erez J (2006) The effect of carbonate chemistry on calcification and photosynthesis in the hermatypic coral Acropora eurystoma. Limnol Oceanogr 51:1284-1293

Shafir S, Van Rijn J, Rinkevich B (2006) Steps in the construction of underwater coral nursery, an essential component

Submitted: January 4, 2008; Accepted: December 1, 2008 in reef restoration acts. Mar Biol 149:679-687

Silverman J, Lazar B, Erez J (2007) Effect of aragonite saturation, temperature, and nutrients on the community calcification rate of a coral reef. J Geophys Res 112:C05004 doi:10.1029/2006JC003770

- Sinclair DJ, Risk MJ (2006) A numerical model of traceelement co-precipitation in a physiochemical calcification system: application to coral biomineralization and traceelement 'vital effects'. Geochim Cosmochim Acta 70: 3855-3868

Smith SV, Buddemeier RV (1992) Global change and coral reef ecosystems. Annu Rev Ecol Syst 23:89-118

Stambler N, Dubinsky Z (2005) Corals as light collectors: an integrating sphere approach. Coral Reefs 24:1-9

> Tambutté E, Allemand D, Zoccola D, Meibom A, Lotto S, Caminiti N, Tambutté S (2007) Observations of the tissueskeleton interface in the scleractinian coral Stylophora pistillata. Coral Reefs 26:517-529

Tanaka Y, Miyajima T, Koike I, Hayashibara T, Ogawa H (2007) Imbalanced coral growth between organic tissue and carbonate skeleton caused by nutrient enrichment. Limnol Oceanogr 52:1139-1146

> Tribollet A, Atkinson MJ, Langdon C (2006) Effects of elevated $\mathrm{pCO}_{2}$ on epilithic and endolithic metabolism of reef carbonates. Glob Change Biol 12:2200-2208

Tribollet A, Godinot C, Atkinson M, Langdon C (in press) Effects of rising atmospheric $\mathrm{pCO}_{2}$ on dissolution of coral reef carbonates by microbial euendoliths. Glob Biogeochem Cycles

Yates KK, Halley RB (2006) $\mathrm{CO}_{3}{ }^{2-}$ concentration and $\mathrm{pCO}_{2}$ thresholds for calcification and dissolution on the Molokai reef flat, Hawaii. Biogeosciences 3:357-369

Zachos JC, Röhl U, Schellenberg SA, Sluijs A and others (2005) Rapid acidification of the ocean during the PaleoceneEocene thermal maximum. Science 308: 1611-1615

Zou D (2005) Effects of elevated atmospheric $\mathrm{CO}_{2}$ on growth, photosynthesis and nitrogen metabolism in the economic brown seaweed, Hizikia fusiforme (Sargassaceae, Phaeophyta). Aquaculture 250:726-735

Proofs received from author(s): December 16, 2008 